\title{
'VL Bean 2': A New Early Dwarf Cultivar of Phaseolus vulgaris L. for Green Pods
}

\author{
Nirmal K. Hedau' ${ }^{1}$, Shri Dhar, Vinay Mahajan, Hari S. Gupta, \\ Karambir S. Hooda, and Vedprakash \\ Vivekananda Institute of Hill Agriculture, Almora, Horticulture, \\ Uttarakhand 263601 (India)
}

Additional index words. Phaseolus vulgaris, early dwarf, green tender pod, stringless

French bean (Phaseolus vulgaris L.) is an important vegetable known as green beans, which is widely cultivated during winter in the subtropics and early spring to fall in temperate zones throughout the world. In India, it is grown in the foothills to higher hills (northwestern Himalayan regions) and North Indian plains (subtropical zone) in different seasons of the year. In India, the French bean breeding program was strengthened with the commencement of the All India Coordinated Research Project on Vegetable Crops (AICRP-VC) in 1971. Only a few bushtype cultivars such as VL Bauni Bean 1, Arka Komal, Contender, and Pant Anupama have been released through AICRP-VC for cultivation in Agro-ecological Zones I (temperate zone) of India (Rai et al., 2004). Because of the dwarf plant habit, short duration, and quality pods, 'Contender' has been widely cultivated by the Indian farmers of northwestern Himalayan states (Uttarakhand, Himachal Pradesh, Jammu, and Kashmir). Hence, in this article, we report the release of 'VL Bean 2', a cultivar with high green pod yield and better horticultural traits such as pod color, shape, and length as compared with those of current cultivars, including 'Contender', available to Indian farmers. This cultivar may be adapted to other temperate regions of the world having similar climatic conditions.

\section{Origin}

Early maturity and dwarf growth habit with attractive stringless green tender pods were the major breeding objectives for the development of the cultivar. In this endeavor, we have selected one parent, 'VL Bauni Bean 1 ', having dwarf growth with high stringless pod yield, and a second parent, 'Contender', having dwarf growth with early maturity and attractive pod shape and color. 'VL Bean 2' was developed by hybridization between 'VL Bauni Bean 1' and 'Contender' through the pedigree method. The crosses between 'VL Bauni Bean 1' and 'Contender' were made in 1996 at the experimental farm of Vivekananda

Received for publication 23 July 2009. Accepted for publication 27 Sept. 2009

${ }^{1}$ To whom reprint requests should be addressed; e-mail hedaunirmal_2003@yahoo.co.in.
Institute of Hill Agriculture, Hawalbagh, Almora, Uttarakhand, India (lat.: $79^{\circ} 39^{\prime} \mathrm{E}$; long.: $29^{\circ} 35^{\prime} \mathrm{N}$; altitude: $1250 \mathrm{~m}$ above sea level). In 1997, $25 \mathrm{~F}_{1}$ seeds were planted and $1245 \mathrm{~F}_{2}$ seeds were harvested in bulk and the subsequent year, $1245 \mathrm{~F}_{2}$ seeds were planted and 210 healthy, superior plants were selected. Later all the individual plant progenies $\left(\mathrm{F}_{3}\right.$ to $\mathrm{F}_{6}$ ) were grown and seeds were collected separately; single plant selections were based on early maturity, dwarf growth, and smooth, tender, stringless green pod. Four uniform progenies with desired traits were selected in the $F_{6}$ generation and plants were grown for further multiplication during the same year.

\section{Description}

The plants of 'VL Bean 2' are characterized by bushy growth, 40 to $45 \mathrm{~cm}$ height, green foliage with pink flowers, eight to 10 pods/plant, pods are green, round, slightly curved, smooth, stringless, short, and pointed tip, $14 \mathrm{~cm}$ long with five to six small seeds/ pod (Figure 1). Seeds are dark brown with slight mottling at maturity. It is early in maturity (first picking is 45 to $50 \mathrm{~d}$ after sowing) and exhibited 50\% flowering in 30 to $35 \mathrm{~d}$ in midhills $1250 \mathrm{~m}$ above sea level. The first week of March for the spring-summer crop and second week of August for the fallwinter crop is suitable for sowing of ' $\mathrm{VL}$ Bean 2' in the midhills of Uttarakhand, India.

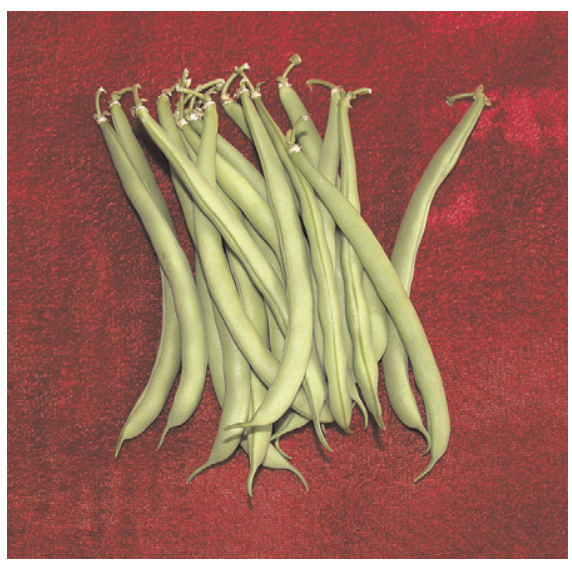

Fig. 1. Pods of 'VL Bean 2'.
A station-replicated trial (prevarietal trial) conducted during 2001 indicated that the green pod yield $\left(9.3 \mathrm{t} \cdot \mathrm{ha}^{-1}\right)$ and number of pods per plant (12.7) of 'VL Bean 2' were much higher than those of the popular cultivars (Table 1). This new cultivar is comparable to other popular cultivars grown in the country in terms of important horticultural traits such as pod shape, color, and length. Because of its superiority over the popular cultivars in the prevarietal trial, it was proposed for State Varietal Trials-Vegetable Crops (SVT-VC) of Uttarakhand India. 'VL Bean 2' along with checks were evaluated in SVT-VC from 2002 to 2005 at Hawalbagh, Almora (1250 m above sea level) and Majhera, Nainital (900 m above sea level) under organic conditions. Evaluation under SVT-VC for 4 years (2002 to 2005) indicated the suitability of 'VL Bean 2' for the midhills of Uttarakhand ( 900 to $1250 \mathrm{~m}$ above sea level) under organic conditions. In both locations, trials were planted in organic blocks of the experimental farm and followed similar organic practice in which farm yard manures were applied at $20 \mathrm{t} \cdot \mathrm{ha}^{-1}$ without any chemicals (insecticide and fungicide). Green pod yield of 'VL Bean 2' was significantly higher than the other cultivars (Table 2). In agronomy trials during 2007, it was evaluated with the popular cultivar Contender in a split-plot design. 'VL Bean 2' was found superior under organic conditions as well as under the integrated nutrient management practice (Table 3). The trials were conducted in the spring-summer seasons and the average rainfall was 30 to $36 \mathrm{~mm}$ and temperature during the period was 25 to $28{ }^{\circ} \mathrm{C}$ (day) and 10 to $12{ }^{\circ} \mathrm{C}$ (night). On the basis of its performance in SVT-VC Uttarakhand, it was identified and recommended for release in the workshop of SVT-VC, Uttarakhand, held at GBPUA\&T, Pantnagar, on 6 Mar. 2006 for its release in Uttarakhand and it was released on 23 July 2008 at Dehradun by State Vegetable Variety Release Committee of Uttarakhand for the midhills (temperate, 900 to $1250 \mathrm{~m}$ above sea level). Finally, it

Table 1. On-station performance ${ }^{\mathrm{z}}$ of lines for green pod yield and yield attributes, 2001.

\begin{tabular}{lcr}
\hline Cultivars & $\begin{array}{c}\text { Green } \\
\text { pod yield } \\
\left(\mathrm{t} \cdot \mathrm{ha}^{-1}\right)\end{array}$ & $\begin{array}{c}\text { No. of } \\
\text { pods per } \\
\text { plant }\end{array}$ \\
\hline VL Bean 2 & $9.3 \mathrm{a}^{\mathrm{y}}$ & $12.7 \mathrm{a}$ \\
VP 9909 & $8.5 \mathrm{~b}$ & $8.3 \mathrm{c}$ \\
VP 2002 & $7.6 \mathrm{c}$ & $8.7 \mathrm{c}$ \\
VP 2006 & $6.2 \mathrm{~d}$ & $10.3 \mathrm{~b}$ \\
VP 2007 & $6.3 \mathrm{~d}$ & $8.0 \mathrm{c}$ \\
Contender (C) & $6.5 \mathrm{~d}$ & $7.7 \mathrm{c}$ \\
VL Bauni Bean 1 (C) & $5.2 \mathrm{e}$ & $7.6 \mathrm{c}$ \\
\hline
\end{tabular}

${ }^{\mathrm{z}}$ Data collected from a prevarietal trial planted in randomized complete block design with three replications.

${ }^{\mathrm{y}}$ Value within columns followed by the different letters are significantly different according to Duncan's test at $P \leq 0.05$.

Plant Density: Row distances $45 \mathrm{~cm}$ and plant to plant $10 \mathrm{~cm}$.

$\mathrm{C}=$ control cultivar. 
Table 2. Performance ${ }^{\mathrm{z}}$ of 'VL Bean 2' at State Varietal Trials-Vegetable Crops, Uttarakhand for green pod yield $\left(\mathrm{t} \cdot \mathrm{ha}^{-1}\right)$ under organic conditions.

\begin{tabular}{lcccccc}
\hline Cultivars & 2002 & 2003 & 2004 & 2005 & $\begin{array}{c}\text { Pooled } \\
\text { mean }\end{array}$ & $\begin{array}{c}\text { Percent increase } \\
\text { of VL Bean 2 }\end{array}$ \\
\hline VL Bean 2 & $13.10 \mathrm{a}^{\mathrm{y}}$ & $8.89 \mathrm{a}$ & $10.62 \mathrm{a}$ & $8.43 \mathrm{a}$ & 9.89 & - \\
VLFB 9909 (Q) & $13.80 \mathrm{a}$ & $7.64 \mathrm{~b}$ & $10.50 \mathrm{a}$ & $8.64 \mathrm{a}$ & 9.84 & +0.51 \\
VL Bauni Bean 1 (C) & $10.74 \mathrm{~b}$ & $6.67 \mathrm{~b}$ & $7.53 \mathrm{~b}$ & $7.92 \mathrm{a}$ & 8.16 & +21.29 \\
Contender (C) & $10.60 \mathrm{~b}$ & $6.39 \mathrm{~b}$ & $7.90 \mathrm{~b}$ & $8.21 \mathrm{a}$ & 8.26 & +19.72 \\
\hline
\end{tabular}

${ }^{\mathrm{z}}$ Data collected from trials planted in randomized complete block designs over the years and locations (V.I.H.A., Hawalbagh, Almora, Uttarakhand and G.B.P.U.A.\& T. Research Station, Majhera, Nainital, Uttarakhand).

${ }^{y}$ Value within columns followed by the different letters are significantly different according to Duncan's test at $P \leq 0.05$.

$\mathrm{Q}=$ qualifying entry; $\mathrm{C}=$ control cultivar.

Table 3. Performance ${ }^{\mathrm{z}}$ of 'VL Bean 2' in agronomy trial conducted at experimental Farm, Hawalbagh for green pod yield $\left(\mathrm{t} \cdot \mathrm{ha}^{-1}\right)$ during 2007.

\begin{tabular}{lcc}
\hline & \multicolumn{2}{c}{ Pod yield $\left(\mathrm{t} \cdot \mathrm{ha}^{-1}\right)$} \\
\cline { 2 - 3 } Fertility levels & VL & Contender \\
$\left(\mathrm{N}: \mathrm{P}_{2} \mathrm{O}_{5}: \mathrm{K}_{2} \mathrm{O}\right)$ & Bean 2 & $(\mathrm{C})$ \\
\hline Organic $\left(20 \mathrm{t} \cdot \mathrm{ha}^{-1} \mathrm{FYM}\right)$ & $11.26 \mathrm{a}^{\mathrm{y}}$ & $9.26 \mathrm{~b}$ \\
25:40:20 $+10 \mathrm{t} \cdot \mathrm{ha}^{-1} \mathrm{FYM}$ & $11.77 \mathrm{a}$ & $8.80 \mathrm{~b}$ \\
$50: 80: 40+10 \mathrm{t} \cdot \mathrm{ha}^{-1} \mathrm{FYM}$ & $12.31 \mathrm{a}$ & $10.19 \mathrm{~b}$ \\
$75: 120: 60+10 \mathrm{t} \cdot \mathrm{ha}^{-1}$ FYM & $12.46 \mathrm{a}$ & $10.92 \mathrm{~b}$ \\
Mean & $11.95 \mathrm{a}$ & $9.79 \mathrm{~b}$ \\
\hline
\end{tabular}

${ }^{\mathrm{z}}$ Data collected from trial planted in a split-plot design.

Value within a row followed by the different letters are significantly different according to Duncan's test at $P \leq 0.05$.

Hawalbagh; Experimental Farm of V.I.H.A., Almora, Uttarakhand.

$\mathrm{FYM}=$ farm yard manure; $\mathrm{C}=$ control cultivar. was notified during the meeting of Central Sub-Committee on Crop Standard Notification and Release for Horticultural Crops (The Gazette of India, 2008).

\section{Availability}

Seeds of 'VL Bean 2' are being multiplied every year and available from Vivekananda Institute of Hill Agriculture, Almora, for Indian scientists and farmers. Seed requests, within India, may be addressed to The Director, Vivekananda Institute of Hill Agriculture, Almora, Uttarakhand, 263 601, India. Seeds of the 'VL Bean 2' have also been deposited at the National Bureau of Plant Genetic Resources (NBPGR), New Delhi under accession no. IC 565200. Seed requests, from outside India, may be addressed to the Director,
National Bureau of Plant Genetic Resources (ICAR), Pusa, New Delhi, 110012, India.

\section{Literature Cited}

Rai, M., S. Kumar, S. Pandey, M. Singh, and B. Singh. 2004. Popular varieties of vegetable crops in India. Technical Bulletin No. 27, IIVR, Varanasi. p. 1-93.

The Gazette of India. 2008. Notification No. SO 2978(E), 17-12/2008-SD IV, 26 Dec. Controller of Publications, New Delhi, India. 